\title{
Streaming Video Perfomance FDD Mode in Handover Process on LTE Network
}

\author{
Cornelis FJ Latupapua*¹, Tri Kuntoro Priyambodo ${ }^{2}$ \\ ${ }^{1}$ Pattimura University, Ambon, Indonesia \\ ${ }^{2}$ Department of Computer Science and Electronics, FMIPA, UGM, Yogyakarta, Indonesia \\ e-mail: *11noell_vb@yahoo.com, ${ }^{2}$ mastri@ugm.ac.id
}

\begin{abstract}
Abstrak
Pada penelitian ini dilakukan simulasi untuk menganalisis performansi video streaming mode FDD dalam proses handover menggunakan Network Simulator 3 dengan 3 cell. Pengamamatan dilakukan pada kecepatan dan jumlah user yang berbeda, dengan mengamati tiga parameter delay, packet loss, dan throughput.

Hasil pengujian menunjukkan bahwa performansi video streaming dalam proses handover pada semua pengujian, tidak dipengaruhi nilai delay. Nilai delay tertinggi masih dalam kategori baik yaitu 153. 43 ms. Nilai packet loss tertinggi adalah 54.5\% dengan 60 user pada kecepatan $100 \mathrm{Km} / \mathrm{jam}$. Nilai throughput tertinggi adalah $0.60 \mathrm{Mbps}$ pada kecepatan 40 $\mathrm{Km} / \mathrm{jam}$ dengan 5 user dan nilai throughput terendah adalah 0.40 Mbps pada kecepatan 60 $\mathrm{Km} / \mathrm{jam}$ dengan 60 user. Performansi terbaik terjadi pada kecepatan $40 \mathrm{Km} / \mathrm{jam}$. Performansi mengalami penurunan pada kecepatan $70 \mathrm{Km} / \mathrm{jam}$ dan $100 \mathrm{Km} / \mathrm{jam}$, karena meningkatnya nilai packet loss dan menurunnya nilai throughput.
\end{abstract}

Kata kunci-Video Streaming, FDD, Handover, LTE

\begin{abstract}
This work was a simulation of LTE networks using Network Simulator 3 with 3 cell for different speed and number of users in order to analyze the video performance of FDD streaming mode in handover process. In this simulation three parameters were observed, i.e. delay, packet loss and throughput.

The results show that the performance of streaming video in handover process on all test, not affected by the value of delay. The highest delay value is $153.43 \mathrm{~ms}$. The highest packet loss is $54.5 \%$ with 60 users at speeds of $100 \mathrm{~km} / \mathrm{h}$. The highest throughput value is $0.60 \mathrm{Mbps}$ at a speed of $40 \mathrm{~km} / \mathrm{h}$ with 5 users and the lowest throughput value is 0.40 Mbps at a speed of 60 $\mathrm{km} / \mathrm{h}$ with 60 users. The best performance achieved at a speed of $40 \mathrm{~km} / \mathrm{h}$. The performance decreased due to increased packet loss and decreased throughput value at speeds of $70 \mathrm{~km} / \mathrm{h}$ and $100 \mathrm{~km} / \mathrm{h}$.
\end{abstract}

Keywords - Video Streaming, FDD, Handover, LTE

\section{INTRODUCTION}

Cellular technology is growing very rapidly, starting from the first generation (1G) which is an analog cellular technology, to the moment that step on the technology of Broadband Wireless Access or also called fourth generation (4G). The growing trend in subscriber demand for services and large-capacity data (Multimedia) and high-speed (Wireless Broadband Access) drives the Third Generation Partnership Project (3GPP) to develop Long Term Evolution (LTE)

Received August $4^{\text {th }}, 2017 ;$ Revised August2 $3^{\text {th }}, 2017$; Accepted December 12 ${ }^{\text {th }}, 2017$ 
technology.

LTE is a $4 \mathrm{G}$ technology that is an advanced evolution of the standard mobile communications system defined by 3GPP (Third Generation Partnership Project) Release 8 capable of realizing Broadband Wireless Access services where all services are based on IP. LTE has several advantages: high spectrum efficiency, low latency, supporting scalable bandwidth from $1.4 \mathrm{MHz}$ to $20 \mathrm{MHz}$, using MIMO (Multi Input Multi Output) technology, using OFDMA (Orthogonal Frequency Division Multiple Access) technique for downlink and SC-FDMA (Single Carrier Frequency Division Multiple Access) for uplink and has downlink data rate of $100 \mathrm{Mbps}$ and uplink of $50 \mathrm{Mbps}$ and allows the user to access the service in a state of moving both in one cell or between cells (Handover) without any termination of communication[1].

To support data services with large and fast capacity such as video streaming, LTE is supported by two modes of FDD (Frequency Division Duplex) and TDD (Time Division Duplex) technology. FDD mode uses two separate frequencies for transmission: uplink transmission and downlink transmission where both transmissions can occur simultaneously. TDD mode uses the same frequency for uplink transmission and downlink transmission [2].

Video streaming is one of telecommunications technology that is real time and can channel information in the form of audio and video. With this streaming video technology, users do not have to wait until the file is finished downloading in its entirety to play it. Instead, users can play the media by waiting a few seconds online. However, there are some issues that affect the performance of streaming video such as the video stops running or slow moves when the user is watching the video so it must wait some time until the video re-runs. In addition, the resulting video quality is also often poor where the video streaming that is watched is less clear and tends to be unclear [3]. This research will analyze the performance of streaming video mode Frequency Division Duplex (FDD) in handover process on LTE network using network simulator NS-3. Research related to streaming video, handover and Frequency Division Duplex (FDD) mode on LTE network has been done by some previous research.

Research [4] has focused research on QoE from video streaming over LTE networks using the Transport Control Protocol (TCP) and User Datagram Protocol (UDP) where video is used with fast motion video and slow motion video. The results show that in the Transport Control Protocol (TCP), slow motion video is better than fast motion video, on the other hand in User Datagram Protocol (UDP), the quality of the two videos is more distorted than video quality in Transport Control Protocol (TCP).

Research [5] has focused research on the performance of video streaming services from the influence of user movement speed on Time Division Duplex (TDD) and Frequency Division Duplex (FDD) networks. The results showed that the performance of LTE network TDD mode and FDD mode when the user experience mobility with high speed, will result in decreased network quality. In this study, it can be seen from the decrease of the average throughput value of each user and the increase of delay and packet loss due to the influence of movement speed and the number of users.

Research [6] has focused research on increasing QoE and video capacity on LTE. The results show that there is a significant potential to optimize the capacity of video through QoE awareness both at the application level and the level of radio access network (RAN).

Research [7] has focused research on evaluating the performance of LTE handover algorithms with multimedia data transmission. The results show that LTE hard handover algorithm with average rsrp constraint (LHHAARC) performs better than LTE hard handover algorithm (LHHA).

Research [8] has focused research on the X2 handover on LTE and LTE- Advanced. The results show that the synchronous uplink procedure obtained through the RACH Medium Access Control (MAC) procedure contributes most to total latency, and that contention-free preambles are preferred to avoid collisions especially high load and mobility scenarios.

Research [9] has focused research on the analysis of handover methods on Wimax networks. The results showed that testing of three scenarios of hard handover and soft handover

IJCCS Vol. 12, No. 1, January 2018 : $43-52$ 
method was done using three times of test where there was difference of time interval between packet delivery and packet receipt, with the amount of traffic sent $64 \mathrm{Kbps}$ (low bandwidth) congestion in the finger can be avoided. The average value of jitter is $0.001 \mathrm{~ms}-0.02 \mathrm{~ms}$ hard handover method and $0.0011 \mathrm{~ms}-0.31 \mathrm{~ms}$ soft handover method, the result shows no significant difference to the test of two handover methods using voice over internet protocol application, so handover mechanism for VoIP service works effectively And ideal on Wimax network.

Research [10] has focused research on vertical handover and horizontal handover on Wifi and Wimax heterogeneous networks with pedestrian users and on trains. The results showed that both vertical handover and horizontal handover, throughput value, delay and packet loss in walking users showed better results than users on trains.

\section{METHODS}

This research will focus on video frequency performance analysis of frequency division duplex (FDD) mode in handover process on LTE network by passing 3 cell with different number of users and speed. There are several steps done in this research are library study, system requirement analysis, design and implementation, testing by using network simulator 3 , analysis of test result, draw conclusion, and create report.

\subsection{Study Library}

This stage is done by searching and studying library materials either from journals, digital libraries, books, ebooks or scientific works related to streaming video, frequency division duplex mode (FDD), handover process on LTE network. At this stage, the author also studies the methods of library materials that have been collected. The result of this study is a list of references to be used in the study.

\subsection{System Requirements Analysis}

This stage is a step performed to describe the simulation needs to be built to simulate streaming video mode Frequency Division Duplex (FDD) in the handover process on the LTE network. The requirements of the required simulations are as follows:

\subsubsection{Hardware Requirements}

The hardware used is Personal Computer already installed Ubuntu Linux operating system version 14.04. The use of Ubuntu linux operating system version 14.04 is tailored to the NS-3-23 simulator software to be used.

\subsubsection{Software Requirements}

The software to be used is Network Simulator 3 software version 23 (NS-3-23). Visualization simulation on Network Simulator 3 using Python and NetAnim.

\subsection{Design and Implementation}

This stage is a step to describe the design of simulation model that will be built to simulate streaming video Frequency Division Duplex (FDD) mode in handover process on LTE network..

\subsubsection{LTE Simulation Model}

The basic concept of a cellular system is the division of services into small areas called cell base stations. Each cell has its own coverage area and operates exclusively with defined service limits. In the LTE Network, each cell comprises an eNodeB tasked with controlling and overseeing the transmission of signals carried by radio signals, playing a role in authentication or controlling the feasibility of data going through eNodeB. In general, the LTE Network 
simulation model consists of several nodes including remote host, SGW / PGW, MME, eNodeB, and User Equipment as in Figure 1.

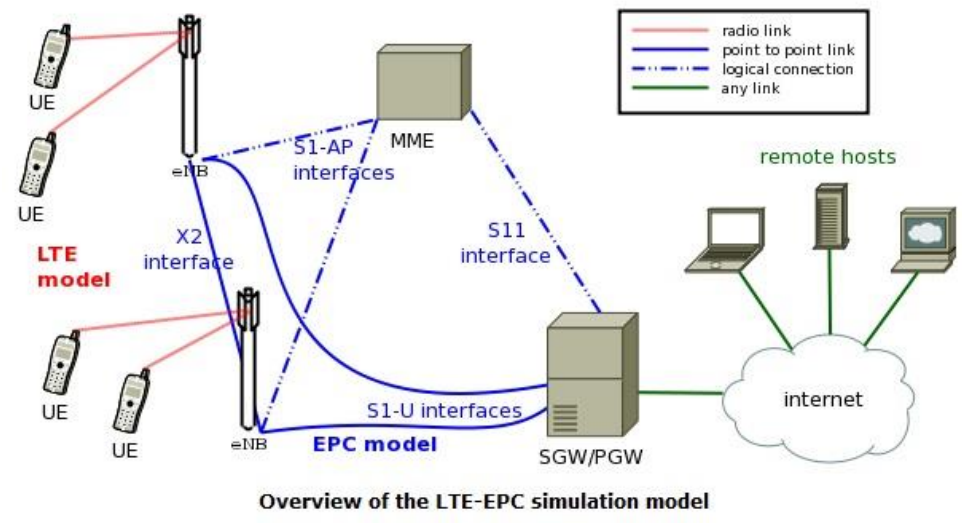

Figure 1 LTE Simulation Model

\subsubsection{Streaming Video Design}

This research uses video streaming application by utilizing LTE network. Video Streaming uses standard H.264 compression video for real-time communication and is supported with TCP / IP protocol for processing and sending data packets. Video streaming is designed with the number of users as many as 60 users where for each test scenario will have a varying number of users. All users will pass 3 cells starting from cell 1, to cell 2 and end in cell 3 with different speed of movement that is $40 \mathrm{~km} / \mathrm{h}, 70 \mathrm{~km} / \mathrm{h}$ and $100 \mathrm{~km} / \mathrm{h}$.

\subsubsection{Handover Mechanism}

The direction of Mobility User Equipment is designed to pass through three cells starting from cell 1, passing cell 2 and ending in cell 3 as shown in Figure 2.

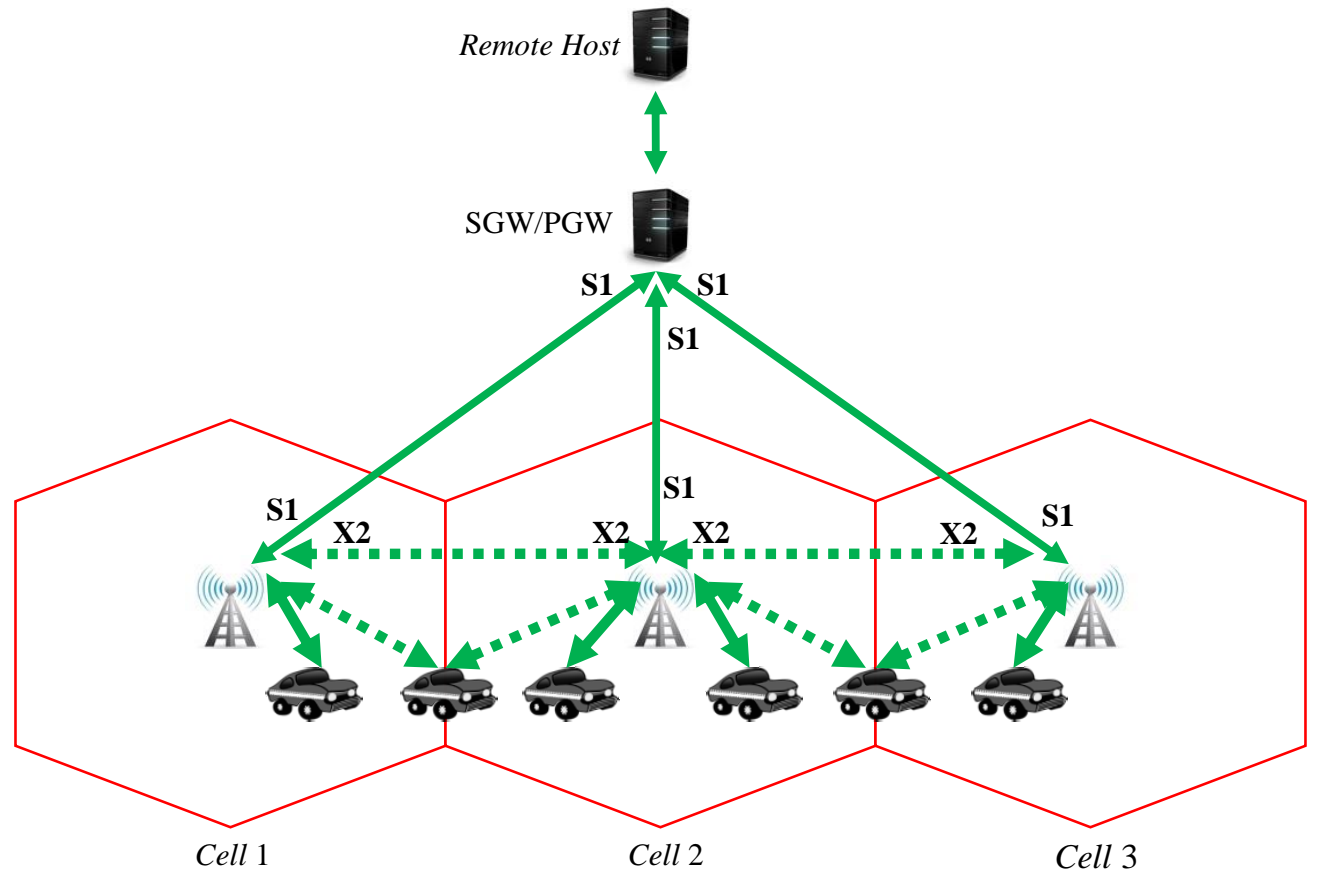

Figure 2 Stages of Handover Process

IJCCS Vol. 12, No. 1, January 2018: 43-52 
When user equipment moves from cell 1 to cell 2 and ends in cell 3, a handover process occurs when user equipment enters the service area where the eNodeB serving decrement is diminishing and performs a service switch to the destination eNodeB. At the time of the handover process, will be measured the value of delay, packet loss and throughput. The handover will be configured using Network Simulator 3 with varying eser equipment and speed of user equipment $40 \mathrm{Km} / \mathrm{h}, 70 \mathrm{Km} / \mathrm{h}$ and $100 \mathrm{Km} / \mathrm{h}$. Stages when eser equipment performs the handover process on the LTE network is as in Figure 3.

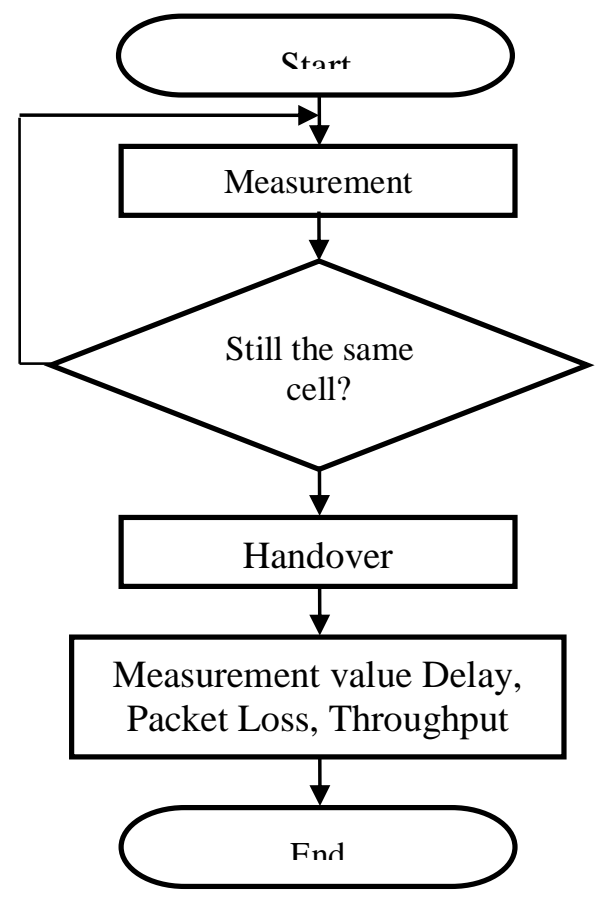

Figure 3 Handover Process Flow

\subsection{Test scenario}

In this research will be done as many as six times of testing with the number of different users and varied with different mobility speed of users. In the test, the user will move from cell 1 to cell 2 and will end in cell 3 where the switching between cells will occur handover process. After doing the handover it will be taken the result of delay, packet loss and throughput to be analyzed. The test scenario can be seen in table 1 .

Table 1 Test Scenario

\begin{tabular}{|c|c|c|c|c|c|c|c|}
\hline $\begin{array}{c}\text { Speed } \\
(\mathrm{Km} / \mathrm{h})\end{array}$ & Scenario & \multicolumn{7}{|c|}{ Number of user } \\
\hline 40 & 1 & 5 & 15 & 25 & 35 & 45 & 60 \\
\hline 70 & 2 & 5 & 15 & 25 & 35 & 45 & 60 \\
\hline 100 & 3 & 5 & 15 & 25 & 35 & 45 & 60 \\
\hline
\end{tabular}

This test is performed to analyze the performance of streaming video in Frequency Division Duplex (FDD) mode in the handover process. The results to be analyzed are: (1) Delay is the total time needed by the packet to travel the distance from the origin (sender) to the destination (receiver), the calculation uses equation (1)

$$
\text { Delay }=\frac{\text { Total packet delivery time }}{\text { Total packets sent }}
$$


(2) Packet Loss which is defined as a packet transmission failure reaches its destination or the number of packets lost, its calculation uses the equation (2)

$$
\text { PakcetLoss } \frac{\text { Packets sent - Packets received }}{\text { Packets sent }} * 100 \%
$$

(3) Throughput is the maximum speed of the network when no data is lost during the transmission process or the number of data received correctly by the user, the calculation uses the equation (3)

$$
\text { Throughput }=\frac{\text { Number of packets sent }}{\text { Packet delivery time }}
$$

\subsection{Implementation}

This research uses Handover.xml animation file found in Network Simulator 3 application where simulation implementation is done using NetAnim. The simulation process can be seen in Figure 4.

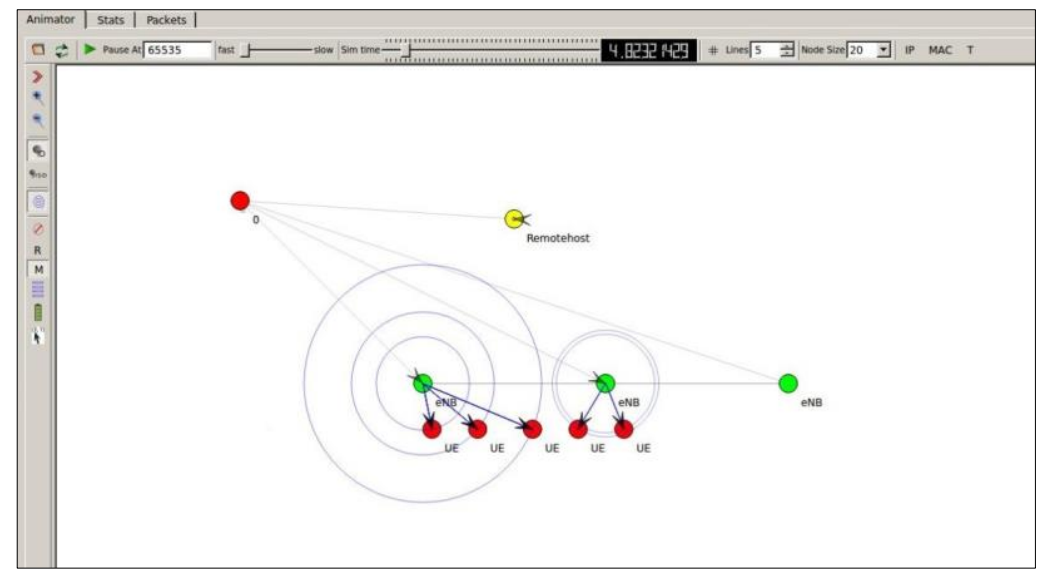

Figure 4 Simulation With NetAnim

\subsection{Data Retrieval}

The process of data retrieval is done by using Flowmonitor found in Network Simulator 3. Data retrieval aims to see the results of the calculation of delay, packet loss and throughput of the handover process that has been done based on the test scenario contained in Table 1. The test results data on the flowmonitor as in Figure 5.

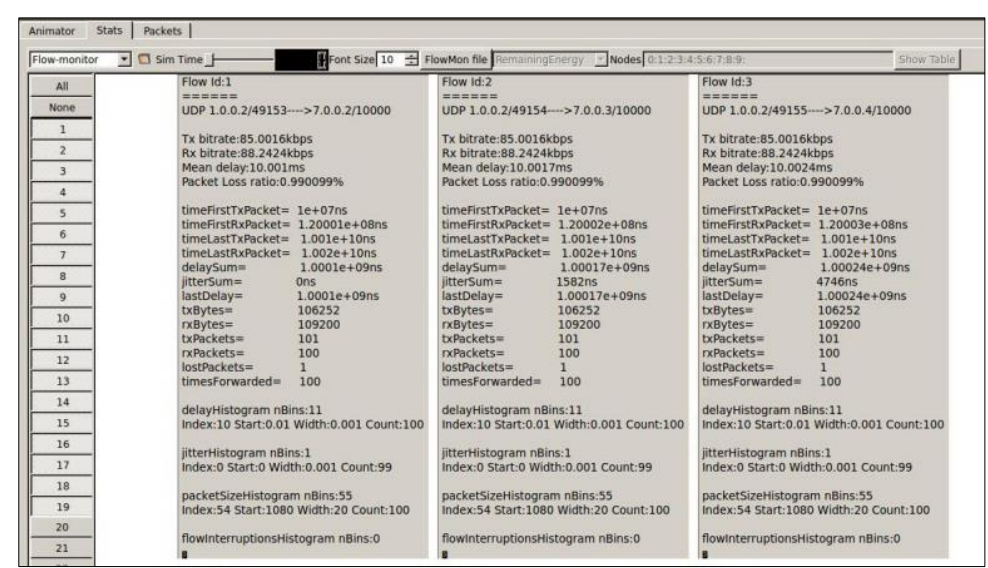

Figure 5 Test Result on Flowmonitor

IJCCS Vol. 12, No. 1, January 2018: $43-52$ 


\section{RESULTS AND DISCUSSION}

The results of this research will be analyzed using the data obtained based on the test scenario phase as in Table 1. This analysis aims to determine the performance of streaming video in the frequency division duplex mode (FDD) in the handover process on the LTE network, with the parameters used are delay, Packet loss and throughput based on the speed and number of different users. The results of each test scenario will be taken as a reference value for steraming video performance analysis during handover process..

\subsection{Delay Result}

Figure 6 shows the average value of delay based on the test scenario that has been done, where the minimum delay range obtained is between $0.23 \mathrm{~ms}$ at a speed of $100 \mathrm{~km} / \mathrm{h}$ for 5 users and the maximum range delay obtained is $0.51 \mathrm{~ms}$ at speed $100 \mathrm{Km} / \mathrm{h}$ for 60 users. For every speed, both at speeds of $40 \mathrm{~km} / \mathrm{h}, 70 \mathrm{~km} / \mathrm{h}$ and $100 \mathrm{~km} / \mathrm{h}$, the value of delay increases as the number of users increases. The result of delay test of all variations of speed and number of users indicates that the delayed value is still eligible and included in both acceptable and acceptable categories according to the time delay grouping based on ITU-T G.114.

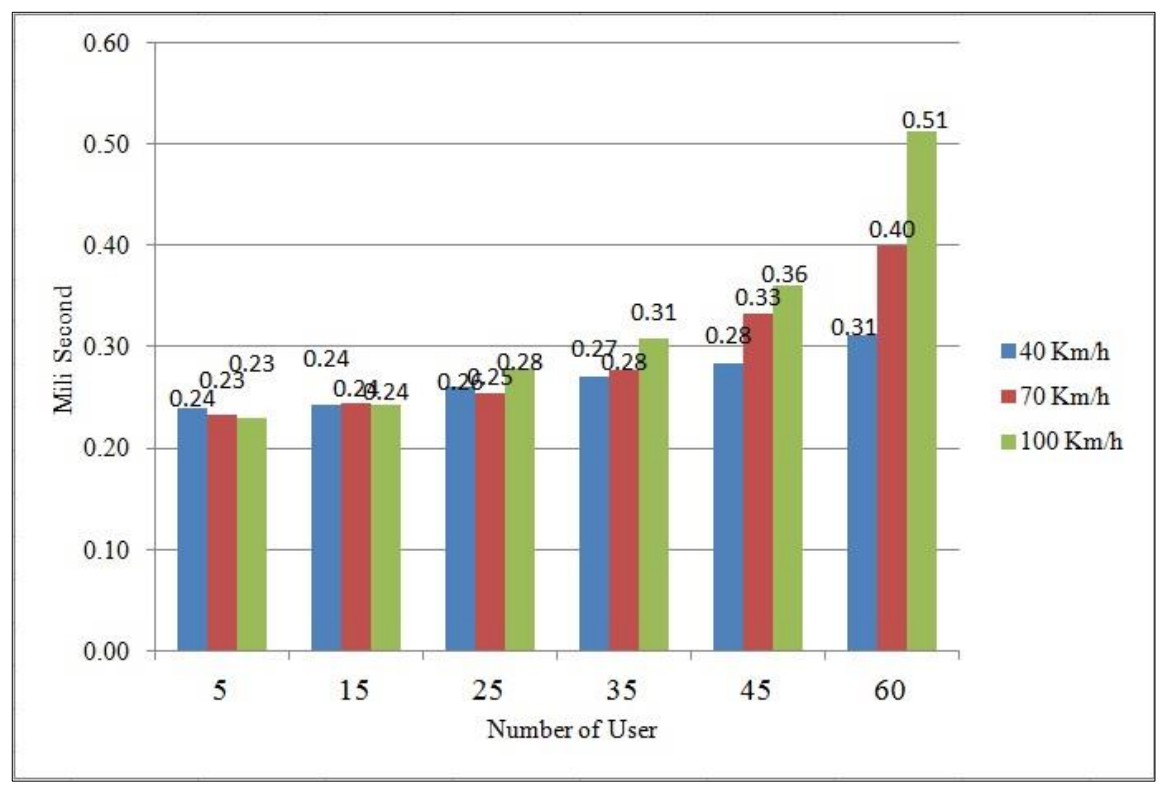

Figure 6 Delay value for speed $40 \mathrm{Km} / \mathrm{h}, 70 \mathrm{Km} / \mathrm{h}$ and $100 \mathrm{Km} / \mathrm{h}$

\subsection{Packet Loss Result}

Gambar 7 menunjukkan besaran nilai rata-rata packet loss ratio berdasarkan skenario pengujian yang telah dilakukan, dimana semakin banyak jumlah user dan semakin tinggi kecepatan maka nilai packet loss ratio yang dihasilkan akan semakin besar. Nilai terendah yang didapatkan adalah pada kecepatan $100 \mathrm{Km} / \mathrm{jam}$ untuk 5 user yaitu sebesar 2,32\% dan nilai tertinggi yang didapatkan adalah pada kecepatan $100 \mathrm{Km} / \mathrm{jam}$ untuk 60 user yaitu sebesar $54,59 \%$. Namun dari hasil pengujian, terdapat anomali nilai packet loss dimana terjadi penurunan nilai pada kecepatan $40 \mathrm{Km} / \mathrm{jam}$ untuk 15 user yaitu $2,87 \%$ dan pada kecepatan 40 $\mathrm{Km} / \mathrm{jam}$ untuk 35 user yaitu $6,09 \%$ serta pada kecepatan $70 \mathrm{Km} / \mathrm{jam}$ untuk 25 user yaitu 3,71 $\%$. Hasil pengujian packet loss dari semua variasi kecepatan dan jumlah user menunjukan bahwa nilai packet loss yang didapatkan ada yang berada dibawah nilai $10 \%$ dan masuk dalam ketegori baik serta masih dapat diterima dan ada yang berada diatas $10 \%$ dan masuk pada kategori buruk yang sesuai dengan pengelompokan packet loss berdasarkan ITU-T G.1010. 


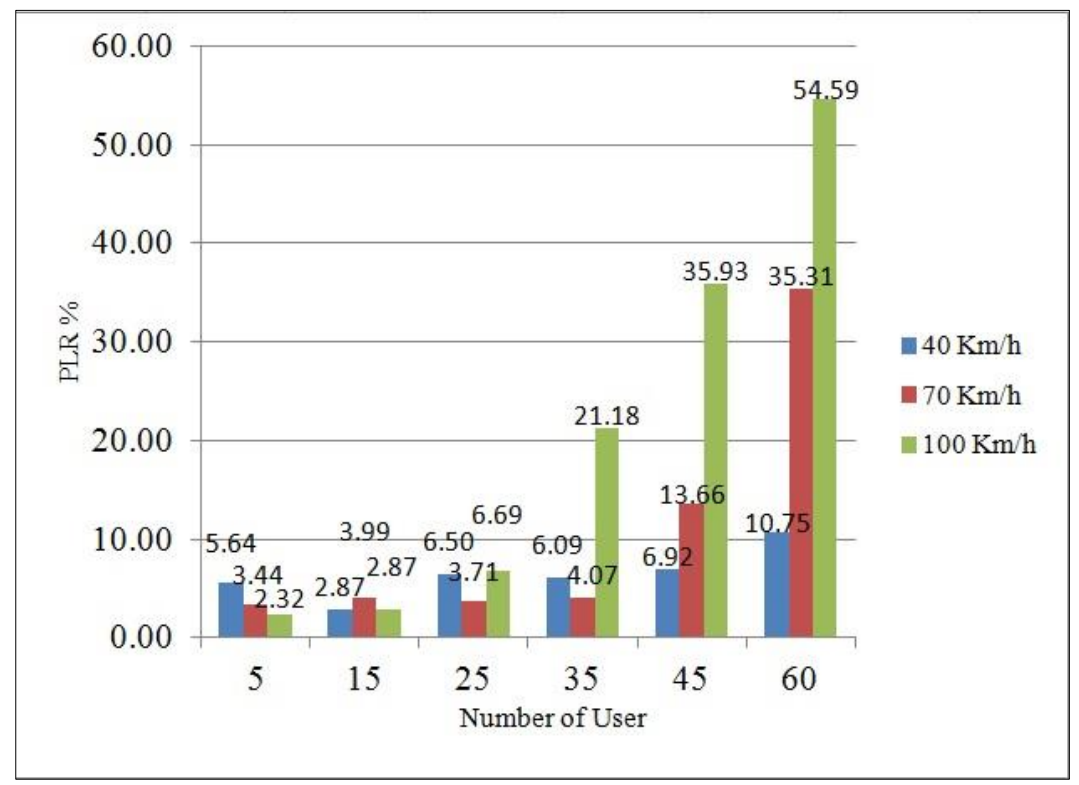

Figure 7 Packet Loss value for speed $40 \mathrm{Km} / \mathrm{h}, 70 \mathrm{Km} / \mathrm{h}$ and $100 \mathrm{Km} / \mathrm{h}$

\subsection{Throughput Result}

Figure 8 shows the average value of throughput based on the test scenario that has been done, where the higher the speed and the more the number of users, the value of throughput decreased. The highest throughput value obtained is $0.63 \mathrm{Mbps}$ at a speed of $100 \mathrm{Km} /$ hour for 5 users and the lowest throughput value obtained is $0.40 \mathrm{Mbps}$ at a speed of $100 \mathrm{~km} / \mathrm{h}$ for 60 users. But from the test results, there is an anomaly throughput value where there is an increase in value at a speed of $40 \mathrm{~km} / \mathrm{h}$ for 15 users of $0.62 \mathrm{Mbps}$ and at a speed of $70 \mathrm{~km} / \mathrm{h}$ for 25 users of $0.62 \mathrm{Mbps}$. The results of throughput testing of all variations in speed and number of users indicate that the obtained throughput values exist in the good category and some are in the medium category corresponding to the throughput grouping based on ITU-T G.1010.

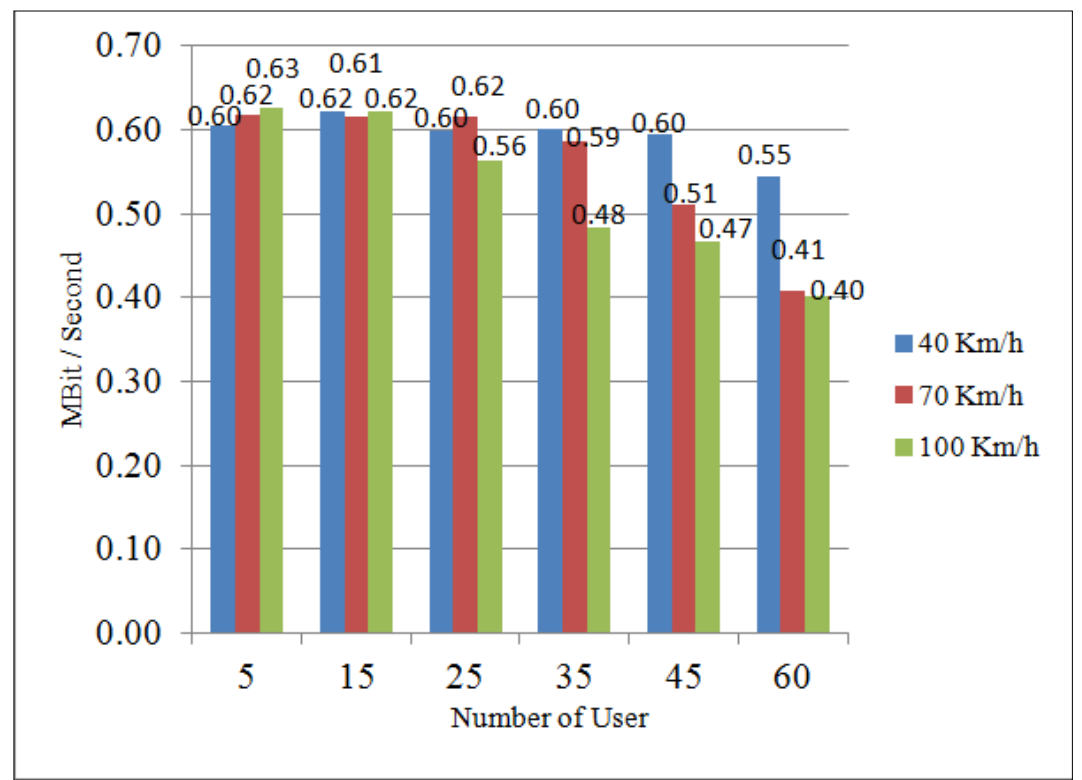

Figure 8 Throughput value for speed $40 \mathrm{Km} / \mathrm{h}, 70 \mathrm{Km} / \mathrm{h}$ and $100 \mathrm{Km} / \mathrm{h}$ 


\section{CONCLUSION}

Based on the research that has been done, it can be obtained some conclusions, including delay testing shows the average value of delay increases when the number of users increases, but the value of the delay obtained from all test scenarios are still eligible and included in both categories and still can received according to group time delay according to ITU-T G.114. In packet loss testing, the results show that the average packet loss value for speeds of $40 \mathrm{~km} / \mathrm{h}$ on all test scenarios still qualifies in both categories and is acceptable, but at speeds of $70 \mathrm{Km} / \mathrm{h}$ for 45 users to 60 users and at speeds of $100 \mathrm{~km} / \mathrm{h}$ for 35 users to 60 users, the value of packet loss goes in the bad category. This is consistent with packet loss grouping based on ITU-T G.1010. shows the average throughput value for speeds of $40 \mathrm{~km} / \mathrm{h}$ in all test scenarios still entering the good category, but at speeds of $70 \mathrm{Km} / \mathrm{h}$ for 60 users and at speeds of $100 \mathrm{~km} / \mathrm{h}$ for 35 users to 60 users, medium category. The throughput values obtained from all test scenarios are still acceptable according to the throughput clustering based on ITU-T G.1010. The performance of streaming video on LTE network during handover process for all test scenarios that have been done shows that the best performance obtained when the user is at a speed of $40 \mathrm{~km} / \mathrm{h}$, at speeds of $70 \mathrm{~km} / \mathrm{h}$ and $100 \mathrm{~km} / \mathrm{h}$, the performance of streaming video has started decreases with increasing packet loss and decreased throughput value. However, the throughput value at a speed of $70 \mathrm{~km} / \mathrm{h}$ and at a speed of $100 \mathrm{~km} / \mathrm{h}$ is still included in an acceptable category.

Based on the conclusion of the results of research that has been done, found there are still some things that need to be refined. As for some suggestions that can be submitted for further research is need to do research to analyze the performance of streaming video between Frequency Division Duplex (FDD) mode with Time Division Duplex (TDD) mode in handover process on LTE network by using simulator that can support both modes. In addition, further research is needed to analyze the performance of streaming video between Frequency Division Duplex (FDD) mode with Time Division Duplex (TDD) mode using S1 handover.

\section{ACKNOWLEDGMENT}

We wish to express our sincere gratitude to all member of Networks and Computer Systems Research Group for their kind co-operation and encouragement.

\section{REFERENCES}

[1] U. K. Usman, G. Prihatmoko, D. K. Hendraningrat, S. D. Purwanto, Fundamental Teknologi Seluler LTE, Rekayasa Sains, 2011.

[2] A. Z. Yonis, M. F. L. Abdullah, and M. F. Ghanim, "LTE-FDD and LTE-TDD for Cellular Communications,” Prog. Electromagn. Res. Symp. Proc., pp. 1467-1471, 2012 [online]. Available: https://www.researchgate.net/publication/267827298 LTEFDD_and_LTE-TDD_for_cellular_communications. [Accessed: 25-Juli-2017].

[3] A. Wulandari, E. B. Purnomowati, and R. Alfanadiah, "Performansi Video Streaming Pada Jaringan LTE ( Long Term Evolution ) Menggunakan Mode Duplex TDD ( Time Division Duplex )," Techno, vol. 12, no. 2, pp. 53-64, 2011 [online]. Available: http://id.portalgaruda.org/?ref=browse \&mod=viewarticle $\&$ article=325675.

[Accessed: 20-Juli-2017] 
[4] P. Uppu and S. Kadimpati, "Master Thesis Electrical Engineering October 2013 QoE of Video Streaming over LTE Network," no. October, 2013 [online]. Available: http://www.diva-

portal.org/smash/record.jsf?pid=diva2\%3A829766\&dswid=1126\#sthash.owGcZPyu.dp bs.[Accessed: 15-Juli-2017]

[5] W. Widayat, I. D. Irawati, and T. A. Wibowo, "KECEPATAN PERGERAKAN USER PADA JARINGAN LONG TERM EVOLUTION ( LTE ) MODE TIME DIVISION DUPLEX ( TDD ) DAN FREQUENCY DIVISION DUPLEX ( FDD ),” 2012 [online]. Avilable:

https://openlibrary.telkomuniversity.ac.id/pustaka/92343/analisis-performansi-layananvideo-streaming-akibat-pengaruh-kecepatan-pergerakan-user-pada-jaringan-long-termevolution-lte-mode-time-division-duplex-tdd-dan-frequency-division-duplex-fdd-.html. [Accessed: 20-Juli-2017].

[6] S. Singh, O. Oyman, A. Papathanassiou, D. Chatterjee, and J. G. Andrews, "Video capacity and QoE enhancements over LTE," IEEE Int. Conf. Commun., pp. 7071-7076, 2012 [online]. Available: http://ieeexplore.ieee.org/abstract/document/6364806/. [Accessed: 20-Juni-2017].

[7] B. V Arun and P. D. Jayaramaiah, "Performance Evaluation of LTE Hard Handover," pp. 3906-3912, 2014 [online]. Available:

https://www.ijircce.com/upload/2014/april/25_Performance.pdf [Accessed: 15-Jul2017].

[8] K. Alexandris, N. Nikaein, R. Knopp, and C. Bonnet, "Analyzing X2 handover in LTE/LTE-A," 2016 14th Int. Symp. Model. Optim. Mobile, Ad Hoc, Wirel. Networks, WiOpt 2016, 2016 [online]. Available: http://ieeexplore.ieee.org/stamp/stamp.jsp?arnumber=7492906 [Accessed: 29-Juni2017].

[9] M. Murhaban and A. Ashari, "Analisa Metode Handover Pada Jaringan WiMAX," IJCCS (Indonesian J. Comput. Cybern. Syst., vol. 10, no. 1, p. 59, 2016 [online]. Available : https://jurnal.ugm.ac.id/ijccs/article/view/11189. [Accessed: 30-Juni-2017].

[10] S. Abdallah-Saleh, Q. Wang, C. Grecos, and D. Thomson, "Handover evaluation for mobile video streaming in heterogeneous wireless networks," Electrotech. Conf. (MELECON), 2012 16th IEEE Mediterr., pp. 23-26, 2012 [online]. Available : http://ieeexplore.ieee.org/document/6196371/. [Accessed: 11-Juli-2017]. 